\title{
PRACOVNÍ POVINNOST STUDENTŮ ZA ČASŮ PANDEMIE COVID-19*
}

\author{
PAVEL KOPECKÝ
}

\begin{abstract}
Mandatory Work Exacted from Students during the Covid-19 Pandemic
The paper deals with an obligation to perform mandatory work which was imposed on specific groups of students during the covid-19 pandemic in the Czech Republic. The first part of the paper handles mandatory work or service generally, and the author deals with the prohibition of forced labour and analyses cases when mandatory work or service may be exacted. The second part is focused on mandatory work exacted during the covid-19 pandemic in 2020, when students of medical and social care disciplines were obligated to perform mandatory work especially in hospitals or retirement houses. The author analyses the government's decisions which imposed mandatory work on students and shows particular problems related to the mandatory work performed by students during the covid-19 pandemic.
\end{abstract}

Keywords: mandatory work; prohibition of forced labour; coronavirus

Klíčová slova: pracovní povinnost; zákaz nucené práce; koronavirus

DOI: $10.14712 / 23366478.2021 .19$

\section{ÚVOD}

Současná pandemie nemoci covid-19, která je nejzávažnější celosvětovou krizí svého druhu za posledních nejméně sto let, s sebou přinesla řadu omezení běžného života, která nemají v poválečné historii, přinejmenším v demokratických částech světa, obdoby. Způsob, jakým jednotlivé státy přistupují k řešení pandemie, se liší, často v důsledku lokálních specifik, opatř̌ení účinná $\mathrm{v}$ jednom státě nemusí být vždy přenositelná do jiných států. V obecné rovině však lze za nejčastější nástroje boje se současnou pandemií označit povinné zakrytí dýchacích otvorů ochrannými prostředky, uzavírání provozoven, uzavírání škol (a přesouvání výuky do on-line prostoru), omezení shromažd’ování, nařizování karantény po styku s nakaženými a po př́ijezdu z cizích zemí. Většina těchto opatření znamená poměrně citelný zásah do základních práv a svobod (napřr. svobody podnikání, svobody shromaždování, svobody volného pohybu, práva na vzdělání atd.), jejich nařizování se proto neobejde bez pevného právního rámce.

Česká republika je státem, který (naštěstí) nemá př́liš velké zkušenosti s řešením krizových stavů: jedná se o vnitrozemský stát nacházející se v mírném podnebném

\footnotetext{
* Tento článek zohledňuje právní stav k 15. 1. 2021 a vznikl v rámci projektu UNCE/HUM/034 Závislá práce v 21. století - otázky a výzvy na Právnické fakultě Univerzity Karlovy.
} 
pásu, existuje zde minimální riziko př́rodních katastrof, jako jsou hurikány, rozsáhlé požáry nebo zemětřesení, je součástí mezinárodních organizací jako NATO a EU, díky čemuž se nemusí obávat př́imého ohrožení ze strany cizích mocností, na rozdíl od jiných evropských států mezi její národní tradice nepatří stávky ani masivní protesty spojené s rabováním, Česká republika nemá naštěstí ani žádné zkušenosti s teroristickými útoky. Největšími krizemi, kterým musela Česká republika po dobu své samostatné existence čelit, byly před propuknutím současné pandemie rozsáhlé povodně v letech 1998 a 2002, nelze se proto divit, že postup orgánů krizového řízení, zejména vlády, byl v mnoha případech poměrně chaotický.

V souvislosti s řešením koronavirové krize byla či stále je využívána řada institutů upravených právním řádem, které do té doby nebyly využity nikdy nebo byly využity pouze v minimálním rozsahu. V souvislosti s koronavirovou krizí si svou ostrou premiéru odbyl i institut pracovní povinnosti upravený zákonem č. 240/2000 Sb., o krizovém řízení (dále jen „KrizZ“). Konkrétně vláda nařídila pracovní povinnost určitému okruhu studentů středních a vysokých škol, a to zejména k zajištění poskytování služeb ve zdravotnických zařízeních a v zařízeních sociálních služeb. Pracovní povinnost studentů byla nařízena $\mathrm{v}$ obou vlnách pandemie, které proběhly v roce 2020, větší využití ovšem našla v tzv. druhé, podzimní vlně koronavirové pandemie.

Oproti jiným krizovým opatřením přijímaným v souvislosti s pandemií se pracovní povinnost vyznačuje řadou specifik. Většina opatření znamená zákaz určitých činností, např. vycházení, shromažd’ování, prodeje, zatímco při pracovní povinnosti musí fyzické osoby logicky určitou činnost vykonávat. Účelem většiny přijímaných ,,protikoronavirových“ opatření je snížit počet nakažených osob či alespoň počet nakažených rozložit v čase, a to pomocí snížení sociálních kontaktů a mobility obyvatelstva na nutné minimum, zatímco nařízená pracovní povinnost studentů měla za cíl řešit nepříznivou situaci ve zdravotnických a sociálních zařízeních (zejm. nemocnicích a domovech seniorů) způsobenou v případě nemocnic zvýšeným počtem hospitalizovaných pacientů a v obou př́padech nedostatkem personálu v důsledku onemocnění a karantény.

Obecně je pracovní povinnost institutem, na který v určité podobě pamatují i nejrůznější mezinárodněprávní dokumenty, v naší právní teorii mu však příliš velká pozornost věnována není. Důvodem je zejména to, že, jak bylo naznačeno výše, pracovní povinnost je v našich podmínkách institutem využívaným výjimečně a z pohledu krizových situací povětšinou poklidné podmínky panující v naší zemi neposkytly právní teorii dostatek impulsů pro to, aby se pracovní povinnosti zevrubněji věnovala. V souvislosti s pracovní povinností se nabízí řada teoretických otázek, přičemž alespoň některé z nich se pokusím nastínit v první části tohoto příspěvku. V jeho druhé části se pak budu snažit věnovat konkrétním otázkám a problémům, které vyvstaly v souvislosti s nařízením pracovní povinnosti studentů během koronavirové pandemie. 


\section{OBECNĚ K PRACOVNÍ POVINNOSTI}

\section{1 ÚSTAVNÍ A MEZINÁRODNĚPRÁVNÍ ASPEKTY}

Jedním ze základních pojmových znaků pracovní povinnosti je její nedobrovolnost. Jak víme, povinnosti mohou být podle čl. 4 odst. 1 Listiny základních práv a svobod (dále jen „Listina“) ukládány toliko na základě zákona a v jeho mezích a jen při zachování základních práv a svobod. Je tedy zřejmé, že pracovní povinnost může být uložena jen na základě zákona a že při jejím ukládání je třeba zachovávat základní práva a svobody. Jak dále vysvětlím, definiční znaky nucené práce, která je obecně zakázaná, a př́ípustné pracovní povinnosti se $\mathrm{v}$ mnohém překrývají. $\mathrm{V}$ souvislosti s pracovní povinností je tedy nutné se vypořádat se zákazem nucených prací a otroctví, který lze zařadit do první, tedy nejstarší generace základních lidských práv. V mezinárodním právu byl zákaz nucené práce zaveden Úmluvou Mezinárodní organizace práce (dále jen „MOP“) č. 29 o nucené nebo povinné práci ze dne 28. června 1930.1 Tato úmluva, která jistě patří mezi významný inspirační zdroj tvůrců Listiny, chápe jako nucenou práci „každou práci nebo službu, která se na kterékoli osobě vymáhá pod pohrůžkou jakéhokoli trestu a ke které se řečená osoba nenabídla dobrovolně". ${ }^{2}$

$\mathrm{V}$ rámci Listiny je zákaz nucených prací upravený v článku 9 zařazeném v oddíle Základní lidská práva a svobody. Podle prvého odstavce tohoto článku nesmí být nikdo podroben nuceným pracím nebo službám. Zákaz nucených prací by však bylo možné dovodit i z obecných ustanovení Listiny i bez jeho explicitního vyjádření v čl. 9.

Nucená práce a služby nejsou v Listině výslovně definovány, to však neznamená, že by v obecné rovině nebylo zřejmé, čeho se zákaz nucených prací a služeb týká. Podle nálezu Ústavního soudu (dále jen „ÚS“) Pl. ÚS 37/93 „jde zpravidla o práce a služby, jež velmi výrazně a omezujícím způsobem zasahují do osobních práv a svobod občana a jejichž nucený výkon představuje donucení administrativní povahy“. Podle O. Moravce nucená práce, tak jak je pojímána v Listině, neútočí oproti otroctví na samotnou podstatu lidské důstojnosti, nýbrž spíše na autonomii jednotlivce a jeho vůle a také na pracovní kapacitu a čas. O. Moravec dále uvádí, že stěžejním prvkem nucené práce je donucení a zčásti také úplatnost. ${ }^{3}$ T. Langášek zastávající mírně odlišný úhel pohledu uvádí, že bezplatnost nemusí být znakem nucené práce, absence odměny však podle něj zpravidla signalizuje nedobrovolnost a zvyšuje tíživost břemene, jež je s takovou prací spojeno, protože není finančně kompenzováno. ${ }^{4}$ Úvahy ohledně otázky odměny můžeme uzavř́it tak, že přítomnost či absence odměny není definičním znakem nucené práce a o nucenou práci půjde i v př́ípadě jejího plného finančního kompenzování. Mnohem podstatnější je nemožnost člověka se svobodně rozhodnout, zda takovou práci bude vykonávat, či nikoli.

1 Úmluva MOP č. 29 byla Československem ratifikována 30. 11. 1957, k jejímu vyhlášení ve Sbírce zákonů však došlo až v roce 1990 pod č. 506/1990 Sb.

2 Článek 2 odst. 1 Úmluvy MOP č. 29.

3 MORAVEC, O. in: HUSSEINI, F. - BARTOŇ, M. - KOKEŠ, M. - KOPA, M. a kol. Listina základních práv a svobod: komentár. Praha: C. H. Beck, 2021, s. 312 a násl.

4 LANGÁŠEK, T. in: WAGNEROVÁ, E. - ŠIMÍČEK, V. - LANGÁŠEK, T. - POSPÍŠIL, I. a kol. Listina základních práv a svobod: komentár. Praha: Wolters Kluwer, 2012, s. 265. 
Podle odstavce 2 článku 9 Listiny se prvý odstavec téhož článku zakazující nucené práce a služby nevztahuje na (mimo jiné) službu vyžadovanou na základě zákona v př́padě živelních pohrom, nehod nebo jiného nebezpečí, které ohrožuje životy, zdraví nebo značné majetkové hodnoty. Ze samotné textace odstavce 2 nelze dovodit, zda se ustanovení odstavce na vyjmenované př́ípady nevztahuje z toho důvodu, že uvedené př́pady nejsou nucenou prací, anebo zda se jedná o výjimky ze zákazu nucené práce, tedy o jakési prípustné formy nucené práce. T. Langášek k tomuto ustanovení ve svém komentáři uvádí: „Odstavec 2 obsahuje výčet situací, které za zakázané nucené práce považovat nelze. Jde o negativní definice, není proto zcela př́padné chápat je jako klasické výjimky a uplatňovat na ně, jakožto na výjimky, automaticky výklad restriktivní, jako by šlo o př́pady ústavně aprobovaných omezení základního práva. " ${ }^{5}$ Opatrnější př́stup k případům uvedeným v odstavci 2 zastává O. Moravec, když uvádí: „Na tyto výluky navazuje podústavní úprava upravujicí konkrétní práva a povinnosti. Toto usporádání vyvolává riziko, že by ústavní úprava mohla být nepř́pustně vykládána prostřednictvím konkretizačních právních předpisů nižši právní síly. Na významu proto nabývá (vedle judikatury ÚS, která je ovšem poměrně řídká) zejména obecný čl. 4 odst. 4, dle něhož při použivání ustanovení o mezích základních práv a svobod musí být šetřeno jejich podstaty a smyslu. Taková omezení nesmějí být zneužívána k jiným účelüm, než pro které byla stanovena. "6 Dle O. Moravce je pracovní povinnost podle č. 9 odst. 2 písm. c) Listiny jednou z výluk, kterou se stanoví meze základního práva. Nejde podle jeho názoru o nic jiného než o založení pravidla, že za určitých, byt' přísně definovaných, podmínek je možno zákaz nucených prací prolomit. ${ }^{7} \mathrm{~V}$ již citovaném nálezu Pl. ÚS 37/93 ÚS k př́padům uvedeným v čl. 9 odst. 2 Listiny stručně uvedl, že , [j]de o případy prací sice vynucených, které však tvoři výjimku ze zákonné zásady zákazu nucených prací nebo služeb “. To odpovídá vnímání pracovní povinnosti jako jedné z přípustných forem nucené práce.

V každém případě je z ústavního hlediska přípustné za určitých podmínek pracovní povinnost nařídit. At' budeme nařízení pracovní povinnosti považovat za výjimku ze zákazu nucených prací, či nikoli, jde o významný, byt' za splnění určitých podmínek přípustný zásah do osobní sféry povinné osoby spočívající např. v nemožnosti se věnovat svému povolání nebo trávit čas podle svého. S nucenou prací má pracovní povinnost v užším slova smyslu společné to, že ji jednotlivec musí vykonávat (zpravidla pod hrozbou veřejnoprávní sankce) bez ohledu na svou vůli, jeho souhlas není vyžadován. Všimněme si též, že Listina (na rozdíl od např. vyvlastnění) nezavádí povinnost pracovní povinnost finančně kompenzovat a tuto otázku zcela ponechává na zákonné úpravě. Rozdíl mezi zakázanou nucenou prací a pracovní povinností spočívá zejména ve veřejném zájmu na jejím vykonání, veřejný zájem na tom, aby jednotlivec vykonával pracovní povinnost, převažuje jeho osobní zájem. $V$ případě řešení situací uvedených v odst. 2 písm. c) ustupuje zájem jednotlivce do pozadí a do popředí se dostávají legitimní celospolečenské zájmy, naopak v př́ípadě zakázané nucené práce má svoboda a vůle jednotlivce absolutní přednost.

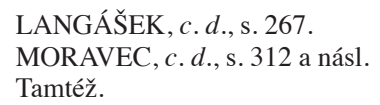


Dle mého názoru je v př́padě nařizování pracovní povinnosti vždy třeba zkoumat nejenom formální splnění ústavních a zákonných podmínek pro nařízení pracovní povinnosti, ale především i proporcionalitu takového kroku, tedy zda nařízení pracovní povinnosti umožní dosáhnout sledovaný cíl (např. záchranu lidských životů nebo majetku), zda by sledovaného cíle nešlo dosáhnout jinými prostředky (např. povoláním armády nebo zapojením dobrovolníků) a zda veřejný zájem na nařízení pracovní povinnosti převyšuje zájem dotčeného jednotlivce na zachování svobody jeho rozhodování. Nařízení pracovní povinnosti v nepřiměřeném rozsahu nebo na dobu delší, než je nezbytné, by i při naplnění hypotézy uvedené v čl. 9 odst. 2 písm. c) (tj. živelní pohroma, nehoda atd.) šlo za ústavně konformní považovat jen stěží, stejně tak zákonnou právní úpravu, která by toto umožňovala.

Úpravu obsaženou v čl. 9 Listiny lze považovat za souladnou s mezinárodními smlouvami, kterými je Česká republika vázána, kromě již zmíněné Úmluvy MOP č. 29 zejména Úmluvou o ochraně lidských práv a základních svobod (dále jen „EÚLP“), která se nuceným nebo povinným pracím věnuje v čl. 4. Podle druhého odstavce čl. 4 se od nikoho nebude vyžadovat, aby vykonával nucené nebo povinné práce. Oproti Listině EÚLP výslovně stanoví, že služba vyžadovaná v případě nouze nebo pohromy, která ohrožuje život nebo blaho společenství, se pro účely čl. 4 za nucenou nebo povinnou práci nepovažuje. Podle EÚLP tedy pracovní povinnost nařízená při mimořádných situacích není (byt' pouze pro účely čl. 4) chápána jako výjimka ze zákazu nucené práce, ale za nucenou práci se nepovažuje. To ovšem nemění nic na podstatě výše řečeného, tedy toho, že služba vyžadovaná v případě nouze nebo pohromy (pracovní povinnost) je významným zásahem do práv a svobod jednotlivce a podmínky pro její nařízení by měly být vykládány spíše restriktivně a se vším respektem k základním lidským právům a svobodám.

Z dalších mezinárodněprávních dokumentů, které se věnují zákazu nucené práce a kterými je Česká republika vázána, můžeme zmínit např. Úmluvu MOP č. 105 z 5 . června 1957 týkající se odstranění nucené práce.

\subsection{ZÁKONNÉ PODMÍNKY PRO NAŘíZENÍ PRACOVNÍ POVINNOSTI}

Co se týče stanovení bližších podmínek pro nařízení pracovní povinnosti, ponechává Listina značný prostor zákonné úpravě. Zákonem, který v České republice upravuje pracovní povinnost, je KrizZ. Tento zákon vymezuje pracovní povinnost jako „povinnost fyzické osoby vykonávat po nezbytně nutnou dobu určenou práci, která je nutná pro řě̌ení krizové situace a kterou je tato osoba povinna konat v místě určeném orgánem krizového řízení “. 8 Vedle pracovní povinnosti zná KrizZ i pracovní výpomoc. Ta se vyznačuje povinností plnit jednorázové a mimořádné úkoly, zatímco pracovní povinnost má oproti pracovní výpomoci spíše dlouhodobější charakter.

Pracovní povinnost může být podle KrizZ vyhlášena během nouzového stavu nebo stavu nebezpečí. Podle ústavního zákona č. 110/1998 Sb., o bezpečnosti České republiky (dále jen „BezpČR“), může nouzový stav vyhlásit vláda v př́ípadě živelních pohrom,

8 § 2 písm. d) KrizZ. 
ekologických nebo průmyslových havárií, nehod nebo jiného nebezpečí, které ve značném rozsahu ohrožují životy, zdraví nebo majetkové hodnoty anebo vnitřní pořádek a bezpečnost. ${ }^{9}$ Nouzový stav lze vyhlásit pro území celé České republiky nebo jeho část. Současně s vyhlášením nouzového stavu musí vláda vymezit, která práva stanovená ve zvláštním zákoně a $\mathrm{v}$ jakém rozsahu se $\mathrm{v}$ souladu s Listinou omezují a které povinnosti a v jakém rozsahu se ukládají. Jednou z těchto povinností může být právě i pracovní povinnost podle KrizZ.

Stav nebezpečí vyhlašuje pro území kraje nebo jeho část hejtman kraje (v hlavním městě Praze primátor). Stav nebezpečí se jako bezodkladné opatření může vyhlásit, jsou-li ohroženy životy, zdraví, majetek, životní prostředí, pokud nedosahuje intenzita ohrožení značného rozsahu a není možné odvrátit ohrožení běžnou činností správních úřadů, orgánů krajů a obcí, složek integrovaného záchranného systému nebo subjektů kritické infrastruktury. ${ }^{10}$

Podle $§ 6$ odst. 1 písm. c) KrizZ je vláda oprávněna v době trvání nouzového stavu na nezbytně nutnou dobu a $v$ nezbytně nutném rozsahu nařídit ukládání pracovní povinnosti. Za stavu nebezpečí je podle $\S 14$ odst. 4 písm. a) KrizZ oprávněn pracovní povinnost nařídit hejtman bez ohledu na vládu.

\subsection{PRACOVNÍ PŘíKAZ}

Pokud vláda za nouzového stavu krizovým opatřením nařídí ukládání pracovní povinnosti určitým skupinám obyvatelstva, je takové opatření obecně závazné, nejsou s ním však spojené bezprostřední právní účinky vůči individuálně určeným osobám, tzn. pouze na základě krizového opatření, kterým se ukládá pracovní povinnost, nelze po fyzických osobách požadovat, aby začaly vykonávat pracovní povinnost. Individuálně určeným osobám vzniká pracovní povinnost až doručením pracovního příkazu. Pracovní příkaz vydává za výše stanovených podmínek hejtman. Podle KrizZ pracovní př́íkaz obsahuje jméno, popřípadě jména, př́ijmení, datum narození a bydliště, den a místo nástupu pracovní povinnosti, druh práce, předpokládanou délku plnění povinnosti, poučení a označení orgánu, který pracovní příkaz vydal.

Zřejmě jedinou formální možností obrany před nezákonným pracovním př́ikazem je podání žaloby ve správním soudnictví. ${ }^{11} \mathrm{O}$ nezákonný pracovní př́íkaz by mohlo jít, napřs. pokud by nebyly splněny výše popsané podmínky pro nařízení pracovní povinnosti, pokud by pracovní př́ikaz vybočoval z mezí krizového opatření vlády nařizujícího ukládání pracovní povinnosti, anebo pokud by byla pracovním př́́kazem povolána osoba, která je od pracovní povinnosti osvobozena. Dosud neřešenou zůstala otázka, jaký žalobní typ by měla osoba bránící se proti pracovnímu př́íkazu zvolit. $\mathrm{V}$ úvahu připadá jak žaloba proti rozhodnutí správního orgánu podle § $65 \mathrm{SŘS}$, tak žaloba na ochranu před nezákonným zásahem, pokynem nebo donucením správního orgánu podle $\S 82$

9 Čl. 5 odst. 1 BezpČR.

$10 \S 3$ KrizZ.

11 Lze však předpokládat, že se dotčené osoby budou proti pracovnímu př́íkazu nejprve bránit neformální cestou, např. sdělením adresovaným krajskému ứradu, že se na ně vztahuje osvobození od pracovní povinnosti. 
SŘS. Osobně bych se s opatrností přiklonil spíše k žalobě proti rozhodnutí, nebot' se domnívám, že pracovní př́íkaz má v materiálním smyslu povahu rozhodnutí ve smyslu SŘS, nebot' se jím závazně určují povinnosti individuálně určené osobě, ${ }^{12}$ a to i presestože se podle všeho nejedná o rozhodnutí ve smyslu správního řádu. Žalobě proti rozhodnutí by nasvědčovala i písemná, formalizovaná podoba pracovního př́íkazu.

\subsection{OSVOBOZENÍ OD PRACOVNÍ POVINNOSTI}

Možnost nařídit pracovní povinnost není neomezená a nelze ji vztáhnout na všechny skupiny obyvatelstva. Pracovní povinnost nelze v prvé řadě uložit osobám, které požívají výsady a imunity podle mezinárodního práva. Ostatním cizincům lze pracovní povinnost uložit, pokud mezinárodní smlouva schválená Parlamentem České republiky a vyhlášená ve Sbírce zákonů a mezinárodních smluv nebo v předcházející obdobné sbírce nestanoví jinak. ${ }^{13}$

Od pracovní povinnosti jsou podle $§ 32$ odst. 2 KrizZ dále osvobozeny

- osoby ve věku do 18 let a od 62 let,

- osoby zdravotně nezpůsobilé k výkonu požadovaných druhů práce,

- osoby invalidní ve třetím stupni, poslanci a senátoři Parlamentu České republiky a členové vlády,

- osoby, které by tím vystavily vážnému ohrožení sebe nebo osoby blízké,

- zaměstnanci subjektu kritické infrastruktury, kteří se podílejí na zajištění funkce prvku kritické infrastruktury,

- ženy a osamělí muži pečující o dítě do 15 let věku, těhotné ženy, ženy do konce třetího měsíce po porodu, jestliže se dítě narodilo mrtvé, zemřelo anebo žena o něj nepečuje.

Ve všech výše uvedených případech mají osoby právní nárok na osvobození od pracovní povinnosti. KrizZ neuvádí, jakým způsobem se důvody pro osvobození od pracovní povinnosti prokazují. Výjimku tvoří osvobození z důvodu zdravotní nezpůsobilosti pro výkon pracovní povinnosti. Tuto skutečnost je podle $§ 31$ odst. 7 KrizZ osoba povinna doložit lékařským posudkem, který vystaví poskytovatel zdravotních služeb určený orgánem, jenž vydal pracovní př́íkaz. ${ }^{14}$ Zákon tedy předpokládá, že osoby, kterým je pracovní povinnost uložena, jsou zdravotně způsobilé a je možné doložit opak. Určený poskytovatel má povinnost provést lékařskou prohlídku a posoudit zdravotní způsobilost $\mathrm{k}$ předpokládané práci přednostně, úhrada nákladů za prohlídku jde k tíži orgánu, který vydal pracovní př́íkaz. ${ }^{15}$ Domnívám se, že kritéria pro posouzení zdravotní způsobilosti pro výkon pracovní povinnosti by měla být shodná s kritérii pro výkon práce obdobného druhu v rámci základních pracovních vztahů, byt' v př́ípadě

\footnotetext{
12 Srov. § 65 odst. 1 SŘS: „Kdo tvrdí, že byl na svých právech zkrácen př́mo nebo v důsledku porušení svých práv v předcházejícím řizení úkonem správního orgánu, jímž se zakládají, mění, ruší nebo závazně určují jeho práva nebo povinnosti, (dále jen ,rozhodnutí), mižze se žalobou domáhat zrušení takového rozhodnutí, popř́padě vyslovení jeho nicotnosti, nestanoví-li tento nebo zvláštní zákon jinak."

$13 \S 32$ odst. 1 KrizZ.

$14 \S 31$ odst. 7 KrizZ.

15 Tamtéž.
} 
pracovní povinnosti bude mít posuzovaná osoba pochopitelně větší zájem na tom, aby byla považována za zdravotně nezpůsobilou.

KrizZ zná kromě výše uvedených důvodů další, fakultativní důvod osvobození od pracovní povinnosti, jehož posouzení závisí na uvážení orgánu krizového řízení. Orgán krizového řízení může osvobodit od pracovní povinnosti a pracovní výpomoci také osoby, kterým by v tom bránila důležitá okolnost, jejíž opominutí by mohlo vést k ohrožení života, zdraví nebo majetku. ${ }^{16}$

Podle $\$ 32$ odst. 3 KrizZ lze ženám uložit pouze takovou pracovní povinnost, která není v rozporu se zvláštním předpisem, tedy zákonem č. 262/2006 Sb., zákoník práce (dále jen ,ZPr“).

\subsection{SANKCE}

Vykonávat pracovní povinnost je veřejnoprávní povinností fyzické osoby, je tedy logické, že s nesplněním této povinnosti je spojena veřejnoprávní sankce. Podle $\S 3$ odst. 1 písm. c) KrizZ se fyzická osoba dopustí přestupku tím, že v době krizového stavu nesplní některou z povinností podle $\$ 31$ odst. 3 písm. d) nebo e), tedy že mimo jiné nesplní povinnost vykonávat uloženou pracovní povinnost. Všimněme si, že jedním ze znaků objektivní stránky přestupku podle $§ 34$ odst. 1 je to, že fyzická osoba svou povinnost nesplní v době nouzového stavu. Zákon tedy nijak nesankcionuje nesplnění pracovní povinnosti nařízené hejtmanem v době stavu nebezpečí.

Za nesplnění povinnosti vykonávat uloženou pracovní povinnost lze uložit pokutu do 50000 Kč. Skutková podstata přestupku může být naplněna např. tím, že fyzická osoba uloženou pracovní povinnost vůbec nezačne vykonávat, anebo ji nevykoná v určeném rozsahu. Při nezahájení pracovní povinnosti bude muset být posuzována otázka, zda fyzická osoba o uložení pracovní povinnosti věděla, tj. zda měla reálnou možnost seznámit se s obsahem pracovního příkazu, odpovědnost za přestupek by však zřejmě bylo možné dovodit i v př́ípadě, kdy by se povinná osoba doručení pracovního příkazu účelově vyhýbala.

\subsection{PRACOVNĚPRÁVNÍ SOUVISLOSTI PRACOVNÍ POVINNOSTI}

Pracovní povinnost není vykonávána v rámci pracovněprávního vztahu, můžeme se však věnovat srovnání postavení osoby vykonávající uloženou pracovní povinnost s postavením osoby vykonávající závislou práci v pracovněprávním vztahu upraveném ZPr. Právní vztah založený pracovním příkazem je specifickým, veřejnoprávním vztahem, KrizZ ani přes svou poměrně velkou stručnost neodkazuje na úpravu v ZPr, jeho subsidiární aplikaci na pracovní povinnost lze dovodit jen stěží. To však neznamená, že by výkon pracovní povinnosti měl stát mimo pozornost pracovního práva, a i z toho důvodu, že jednou z hlavních funkcí pracovního práva je funkce ochranná. Ani mimořádnost okolností, za kterých může být pracovní povinnost uložena, by neměla vést $\mathrm{k}$ degradaci postavení osob vykonávajících pracovní povinnost.

$16 \S 32$ odst. 2 KrizZ. 
Přes výše řečené se domnívám, že výkon pracovní povinnosti naplňuje znaky závislé práce, jak ji definuje ZPr v $§ 2$ odst. 1. Podle tohoto ustanovení je závislou prací práce, která je vykonávána ve vztahu nadřízenosti zaměstnavatele a podřízenosti zaměstnance, jménem zaměstnavatele, podle pokynů zaměstnavatele a zaměstnanec ji pro zaměstnavatele vykonává osobně. Pokud přistoupíme na to, že orgán krizového řízení plní roli kvazizaměstnavatele, dojdeme při jen mírně extenzivním výkladu uvedených znaků k závěru, že pracovní povinnost zákonnou definici závislé práce naplňuje.

Ačkoli výkon pracovní povinnosti může být považován za určitý výkon závislé práce, nenáleží za ni fyzické osobě mzda, plat ani jiná odměna, ale pouze finanční náhrada, kterou je povinen vyplatit orgán krizového řízení, který o uložení pracovní povinnosti rozhodl. ${ }^{17}$ Náhradu, tak jak ji KrizZ upravuje, nelze považovat za určitou formu výdělku, ale skutečně pouze jako kompenzaci času stráveného nedobrovolně a pod hrozbou sankce při výkonu pracovní povinnosti. K výši náhrady § 35 odst. 3 KrizZ uvádí: „Jde-li o vykonání pracovní povinnosti, pracovní výpomoci nebo dobrovolné pomoci, u nichž nelze určit výši náhrady dohodou nebo postupem podle občanského zákoníku, stanoví se náhrada ve výši, která odpovídá obvyklé mzdě za stejné či podobné práce." Lze předpokládat, že ve většině př́ípadů nebude možné výši náhrady určit dohodou ani postupem podle občanského zákoníku a náhrada bude muset být určena jednostranně orgánem krizového řízení, který pracovní povinnost nařídil. Peněžní náhrada se vyplácí do 6 měsíců od ukončení nebo zrušení krizového stavu, v jehož důsledku nárok na peněžní náhradu vznikl. ${ }^{18}$ Právě způsob stanovení náhrady za výkon pracovní povinnosti a dobu její splatnosti považuji za jednu z nejproblematičtějších otázek týkajících se zákonné úpravy pracovní povinnosti. Uložení pracovní povinnosti může pro řadu osob znamenat nemožnost vykonávat jejich běžné zaměstnání či jinou výdělečnou činnost, která je pro ně zdrojem obživy. Z pohledu ZPr lze výkon pracovní povinnosti považovat za překážku v práci na straně zaměstnance $\mathrm{z}$ důvodu obecného zájmu, za kterou zaměstnanci nenáleží náhrada mzdy. ${ }^{19}$

Jakkoli je nařízení pracovní povinnosti odůvodnitelné veřejným zájmem, který přesahuje zájmy jednotlivce, domnívám se, že nařízení pracovní povinnosti by se nemělo negativně projevit na příjmové stránce osob, jimž byla pracovní povinnost nařízena. Náhrada za výkon pracovní povinnosti by měla reflektovat nejenom povahu práce, kterou osoba s nařízenou pracovní povinností vykonávala, ale také by měla kompenzovat výdělek, o který tato osoba v důsledku vykonávání pracovní povinnosti přišla. KrizZ přistupuje k náhradě za vykonání pracovní povinnosti podobně jako k náhradě omezení vlastnického nebo užívacího práva nebo náhradě za poskytnutí věcného prostředku, čímž degraduje lidskou práci na úroveň věcných práv. Stejně tak nelze za přiměřenou považovat délku zákonné lhůty, ve které má být náhrada vyplacena. Při ztrátě pravidelného výdělku v důsledku nařízené pracovní povinnosti se šestiměsíční lhůta jeví jako nepřiměřeně dlouhá. Její běh navíc není nikterak vázán na dobu, kdy byla pracovní povinnost vykonávána, ale počítá se od konce krizového stavu, v jehož rámci byla pracovní povinnost nařízena.

$17 \S 35$ odst. 1 KrizZ.

18 Tamtéž.

19 Viz § 200 v kombinaci s $§ 202$ ZPr. 


\section{KONKRÉTNĚ K PRACOVNÍ POVINNOSTI V PRŮBĚHU PANDEMIE NEMOCI COVID-19}

\subsection{NAŘÍZENÍ PRACOVNÍ POVINNOSTI A JEJÍ ROZSAH}

Události roku 2020 učinily z teoretických otázek, které jsem se pokusil řešit $\mathrm{v}$ předchozí části tohoto textu, otázky praktičtější více, než by se komukoli z nás mohlo v ještě nedávné době zdát. V souvislosti s pandemií nemoci covid-19 Česká republika v roce 2020 zažila dvojí vyhlášení nouzového stavu, přičemž druhé období nouzového stavu přetrvává i na počátku roku 2021 v době odevzdání tohoto textu. Poprvé byl nouzový stav vyhlášen 12. března 2020 usnesením vlády vyhlášeným pod č. 69/2020 Sb., a to ,z důvodu ohrožení zdraví v souvislosti s prokázáním výskytu koronaviru (označovaný jako SARS CoV-2) na území České republiky“. ${ }^{20}$ Doba trvání ,prvního“ nouzového stavu byla opakovaně prodloužena Poslaneckou sněmovnou a tento nouzový stav skončil po více než dvou měsících trvání 17. května 2020. Po letním intermezzu byl nouzový stav s uvedením stejných důvodů jako v březnu opět vyhlášen 30. záŕí 2020 s účinky od 5. října 2020 usnesením vlády vyhlášeným pod č. 391/2020 Sb. Pandemii nemoci covid-19 lze považovat za „nebezpečí, které ve značném rozsahu ohrožuje životy a zdraví “, 21 a z tohoto pohledu lze vyhlášení nouzového stavu považovat za legitimní a důvodné.

Bez právního rámce poskytovaného nouzovým stavem by vláda nemohla přijímat řadu plošných protiepidemických opatření, pokusy obejít rámec nouzového stavu a přenést některé pravomoci vlády zasahující do základních práv a svobod garantovaných Listinou na ústřední správní úřady se ukázaly jako nezákonné. ${ }^{22}$ Možnost nařídit pracovní povinnost nelze považovat za důvod vyhlášení nouzového stavu, spíše lze nařízení pracovní povinnosti považovat za využití jedné z možností poskytnutých nouzovým stavem. Usnesením, kterými byl vyhlášen nouzový stav, je po formální stránce vytýkáno, že v rozporu se zněním BezpČR ${ }^{23}$ i předchozí praxî́24 nevymezují, která práva stanovená ve zvláštním zákoně a v jakém rozsahu se v souladu s Listinou omezují a které povinnosti a $\mathrm{v}$ jakém rozsahu se ukládají, a to ani v obecné rovině.

Vláda využila možnosti nařídit ukládání pracovní povinnosti v rámci obou období nouzového stavu vyhlášených v roce 2020, přesněji nařídila hejtmanům ukládání pracovní povinnosti vybraným skupinám studenstva.

V návaznosti na usnesení vlády, kterým vláda vyhlásila nouzový stav, vláda svým usnesením z 13. března 2020 vyhlášeným pod č. 79/2020 Sb., o zajištění poskytování péče v zařízeních sociálních služeb po dobu trvání nouzového stavu, uložila , $k z a$ jištění poskytování péče v zařizeních sociálních služeb po dobu platnosti nouzového

20 Viz uvedení důvodu vyhlášení nouzového stavu v usnesení vlády č. 69/2020 Sb. Uvedení důvodů je podle čl. 6 BezpČR povinnou náležitostí vyhlášení nouzového stavu.

21 Srov. podmínky pro vyhlášení nouzového stavu v čl. 5 odst. 1 BezpČR.

22 Viz rozsudek Městského soudu v Praze ze dne 23. dubna 2020, sp. zn. 14 A 41/2020, kterým byla zrušena mimořádná opatření Ministerstva zdravotnictví, která zakazovala např. maloobchodní prodej nebo poskytování služeb v provozovnách.

23 Srov. čl. 6 BezpČR.

24 Srov. např. rozhodnutí vlády ČR č. 11/2007 Sb. 
stavu v souvislosti s výskytem epidemie COVID-19 na území České republiky pracovní povinnost studentům v denní formě studia vyšších odborných a vysokých škol v oborech vzdělání podle § 110 odst. 4 písm. a) a b) zákona č. 108/2006 Sb., o sociálních službách, ve znění pozdějších předpisů, a studentüm středních škol v oborech vzdělání podle př́lohy č. 4 vyhlášky č. 505/2006 Sb., kterou se prováději některá ustanovení zákona o sociálních službách, ve znění pozdějších předpisü“.

V souvislosti s prováděním nařízené pracovní povinnosti vláda dále uložila dílčí povinnosti ministryni práce a sociálních věcí, ministru školství, mládeže a tělovýchovy a hejtmanům krajů a primátorovi hl. m. Prahy. Ne př́iliš vysoké legislativně technické úrovni přisvědčuje to, že vláda okruh osob (studentů), na které se pracovní povinnost vztahuje, nevymezuje přímo, ale odkazem na ustanovení zvláštních právních předpisů. Odkazovaný § 110 odst. 4 zákona o sociálních službách stanoví obory, jejichž absolvováním je možné získat odbornou způsobilost k výkonu povolání sociálního pracovníka, konkrétně se jedná o

- vyšší odborné vzdělání získané absolvováním vzdělávacího programu akreditovaného podle zvláštního právního předpisu v oborech vzdělání zaměřených na sociální práci a sociální pedagogiku, sociální pedagogiku, sociální a humanitární práci, sociální práci, sociálně právní činnost, charitní a sociální činnost,

- vysokoškolské vzdělání získané studiem v bakalářském, magisterském nebo doktorském studijním programu zaměřeném na sociální práci, sociální politiku, sociální pedagogiku, sociální péči, sociální patologii, právo nebo speciální pedagogiku, akreditovaném podle zvláštního právního předpisu.

Tímto se mezi studenty, kterým byla nařízena pracovní povinnost, dostali např. i studenti právnických fakult. Ačkoli je absolvováním oboru právo a právní věda možné získat odbornou způsobilost pro výkon povolání sociálního pracovníka, nelze říci, že by studenti právnických fakult měli předpoklady k zajištění poskytování péče v zařízeních sociálních služeb větší než např. studenti technických oborů. Odkazovaná příloha č. 4 vyhlášky č. 505/2006 Sb. vymezuje obory vzdělání, při jejichž absolvování se nevyžaduje absolvování kvalifikačního kurzu pro pracovníky v sociálních službách.

Dne 15. března 2020 vláda svým usnesením vyhlášeným pod č. 90/2020 Sb. rozhodla k zajištění poskytování zdravotních služeb poskytovateli zdravotních služeb a k zajištění činnosti orgánů ochrany veřejného zdraví po dobu platnosti nouzového stavu v souvislosti s výskytem epidemie covidu-19 na území České republiky o uložení pracovní povinnosti žákům a studentům

- pátého a šestého ročníku prezenční formy studijního programu všeobecné lékařství na lékařských fakultách veřejných vysokých škol,

- posledních ročníků denní nebo prezenční formy studijních programů či oborů vzdělání připravujících na profesi:

- všeobecná sestra, a to $\mathrm{v}$ bakalářském studijním programu pro přípravu všeobecných sester nebo v oboru vzdělání diplomovaná všeobecná sestra na vyšších odborných školách,

- dětská sestra, a to $\mathrm{v}$ bakalářském studijním programu pro přípravu dětských sester nebo oboru vzdělání diplomovaná dětská sestra na vyšších odborných školách, 
- zdravotnický záchranár̆, a to $\mathrm{v}$ bakalářském studijním programu pro prŕípravu zdravotnických záchranářo nebo oboru vzdělání diplomovaný zdravotnický záchranář na vyšších odborných školách,

- asistent ochrany a podpory veřejného zdraví, a to v bakalářském studijním programu pro př́ípravu asistentů ochrany a podpory veřejného zdraví,

- praktická sestra, a to v oboru vzdělání praktická sestra a zdravotnický asistent na střední škole.

Tímto usnesením vláda dále pověřila ministra zdravotnictví informačním a metodickým vedením a ministra školství, mládeže a tělovýchovy, aby poskytl Ministerstvu zdravotnictví veškerou potřebnou součinnost.

Vláda dále uložila všem orgánům ochrany veřejného zdraví, všem poskytovatelům zdravotnické záchranné služby a poskytovatelům zdravotních služeb uvedených v př́iloze $\mathrm{k}$ tomuto usnesení ${ }^{25}$ využívat na svém území pracovní povinnost osob uvedených v bodu 1 usnesení a informovat Ministerstvo zdravotnictví o přijatých opatřeních v tomto směru. Tímto vláda $\mathrm{v}$ zásadě vymezila okruh osob a vykonavatelů veřejné správy, které mohou pracovní povinnosti v případě potřeby využít. Zajímavé je, že vláda v tomto usnesení vůbec nezmiňuje hejtmany, kteří vydávají pracovní př́íkazy.

Lze diskutovat nad tím, zda tento způsob nařízení ukládání pracovní povinnosti odpovídá požadavkům BezpČR, zejména z toho důvodu, že pokud vláda nevymezila současně s vyhlášením nouzového stavu, která práva stanovená ve zvláštním zákoně a v jakém rozsahu se omezují a které povinnosti a v jakém rozsahu se ukládají, nařízení ukládání pracovní povinnosti několik dnů po vyhlášení nouzového stavu nelze v žádném případě považovat za provedené současně s vyhlášením nouzového stavu. $\mathrm{S}$ určitou opatrností lze konstatovat, že takové nařízení pracovní povinnosti není v plném souladu $\mathrm{s}$ ústavním pořádkem. Za s ústavním pořádkem souladné bych považoval, kdyby vláda v usnesení, kterým vyhlašovala nouzový stav, uvedla, že se ukládá pracovní povinnost např. k zajištění poskytování zdravotních služeb, a tato povinnost by byla konkretizována v navazujících usneseních.

Pracovní povinnost uložená výše uvedenými usneseními vlády byla zrušena k 11. květnu 2020. Institut pracovní povinnosti byl využit opět v souvislosti s tzv. druhou vlnou pandemie koronaviru, v rámci nouzového stavu, který byl vládou vyhlášen 30. září s účinností od 5. října. Konkrétně bylo ukládání pracovní povinnosti nařízeno usneseními vlády vyhlášenými pod č. 409/2020 Sb. a 411/2020 Sb.

Usnesení č. 409/2020 Sb. směřovalo k ,zajišstění poskytování zdravotních služeb poskytovateli zdravotních služeb a k zajištění činnosti orgánů ochrany veřejného zdraví po dobu trvání nouzového stavu " a ukládalo pracovní povinnost studentům

a) čtvrtého a pátého ročníku prezenční formy studijního programu všeobecné lékařství na lékařských fakultách veřejných vysokých škol,

b) pátého ročníku prezenční formy studijního programu zubní lékařství na veřejné vysoké škole,

25 V zásadě se jedná o velké, krajské či fakultní nemocnice, např̀. Nemocnici Na Bulovce, Fakultní nemocnici v Motole, Nemocnici Na Homolce, Krajskou nemocnici T. Bati, a. s. 
c) pátého ročníku prezenční formy studijního programu farmacie na veřejné vysoké škole,

d) posledních ročníků denní nebo prezenční formy bakalářských a pětiletých magisterských studijních programů na vysoké škole nebo oborů vzdělání na vyšší odborné škole nebo střední zdravotnické škole připravujícím se na nelékařské zdravotnické povolání podle zákona č. 96/2004 Sb., o podmínkách získávání a uznávání způsobilosti k výkonu nelékařských zdravotnických povolání a k výkonu činností souvisejících s poskytováním zdravotní péče a o změně některých souvisejících zákonů (zákon o nelékařských zdravotnických povoláních), ve znění pozdějších předpisů, a bakalářského nebo pětiletého magisterského programu jednooborové psychologie, e) všech ročníků prezenční formy zdravotnických magisterských studijních programů navazujících na zdravotnický bakalářský program a magisterského programu jednooborové psychologie navazujícího na bakalářský program.

Můžeme si všimnout, že oproti ,první vlně“ došlo k rozšr̂rení okruhu studentů, jimž byla pracovní povinnost nařízena, a to o studenty zubního lékařství, farmacie a psychologie a o studenty dalších nelékařských oborů podle zákona o podmínkách získávání a uznávání způsobilosti k výkonu nelékařských zdravotnických povolání a k výkonu činností souvisejících s poskytováním zdravotní péče. Dále si můžeme všimnout, že břímě pracovní povinnosti bylo v případě mediků přeneseno na studenty 4. a 5. ročníku, zatímco studentům posledních, 6. ročníků byla na podzim pracovní povinnost „odpuštěna“. Usnesení č. 409/2020 Sb. bylo zrušeno 14. prosince s účinností k 16. prosinci, ${ }^{26}$ bod, podle kterého byla nařízena pracovní povinnost mediků, však byl bez větší logiky na rozdíl od ostatních oborů zrušen již 7. prosince (s účinností k 10. prosinci).

Usnesením č. 411/2020 Sb. byla k ,zajištění poskytování sociálních služeb a $k$ zajištění poskytování péče $v$ zařizeních pro děti vyžadujicí okamžitou pomoc " nařízena pracovní povinnost stejnému okruhu studentů oborů se sociálním zaměřením, jediným významnějším rozdílem oproti usnesení 79/2020 Sb. je, že toto usnesení výslovně vyjímá právní obory. Toto usnesení bylo spolu se „zdravotnickým“ usnesením č. 409/2020 zrušeno k 16. prosinci.

\subsection{K JEDNOTLIVÝM PROBLÉMU゚M A OTÁZKÁM SPOJENÝM S PRACOVNÍ POVINNOSTÍ STUDENTŮ}

Masivnější využití pracovní povinnosti v době pandemie nemoci covid-19 s sebou přineslo řadu praktických problémů, zároveň vyvstaly otázky, kterými by zřejmě za běžné situace nikoho nenapadlo se v souvislosti s institutem pracovní povinnosti zabývat. Různé zmatky spojené s nařízenou pracovní povinností lze částečně klást za vinu poměrně stručné právní úpravě tohoto institutu. Nelze však jednoznačně říci, že podrobnější úprava by situaci zlepšila, při řešení krizových situací je důležitá rychlost a větší míra formalismu by mohla řešení krizových stavů komplikovat. KrizZ jednoduše nepočítá s tím, že by pracovní povinnost mohla být využívána takovým způsobem a po tak dlouhou dobu, jako tomu bylo během pandemie covidu-19, tedy že by osoby

26 Ke zrušení došlo usnesením vlády č. 537/2020 Sb. 
s nařízenou pracovní povinností po dobu několika týdnů pravidelně docházely na směny do zdravotnických či sociálních zařízení, kde by konaly stejnou práci jako osoby v pracovněprávních vztazích. KrizZ je stavěn spíše na situace, jako jsou např. povodně, kdy je nutné, aby v poměrně krátkém čase došlo k provedení úkonů, které bezprostředně mîrí k ochraně lidských životů nebo majetku, např. stavění hrází, plnění pytlů s pískem, odklízení naplavenin. V případě krátkodobé pracovní povinnosti je přípustné, aby byla náhrada vyplacena až za 6 měsíců od skončení nouzového stavu, čím déle však pracovní povinnost trvá, tím více se takový přístup stává prekérním.

Minimálně část odpovědnosti za zmatky spojené s nařízenou pracovní povinností jde za vládou, která sice pracovní povinnost nařídila a postarala se tak o personální zajištění zejména v nemocnicích, rezignovala však na další metodické řízení pracovní povinnosti. Důsledkem toho je nejednotný přístup napříč jednotlivými kraji a zařízeními využívajícími pracovní povinnost, a především nejistota studentů. V první části tohoto textu jsem se snažil institut pracovní povinnosti popsat jako výjimečný institut, který je velkým zásahem do osobní sféry jedince, a z toho důvodu by měl být využíván jen v mimořádných př́ípadech. Současná situace sice výjimečná je, z ničeho však nevyplývá, že by při nařizování pracovní povinnosti vláda provedla test proporcionality, ze kterého by jasně vyplývalo, že nařízení pracovní povinnosti studentům středních a vysokých škol je nejvhodnějším řešením a proč má být pracovní povinnost nařízena právě studentům. Studenti pak měli oprávněně pocit, že je vláda pouze využila jako levnou pracovní sílu a že si je vybrala jako zranitelnou skupinu, která nemá př́liš mnoho možností se účinně bránit. To však neznamená, že by studenti nechtěli př́i současné krizi pomáhat - řada studentů, zejména mediků, pracuje či pracovala v nemocnicích, včetně tzv. covidových oddělení, dobrovolně, z vlastní iniciativy. Od vypuknutí pandemie se studenti začali sami organizovat a i přes své studijní povinnosti nabízeli svou výpomoc v nemocnicích. Je také třeba upozornit, že využití pracovní povinnosti pro řešení koronavirové krize je minimálně v evropském srovnání ojedinělé. Pokud bylo využití pracovní povinnosti v takovém rozsahu skutečně nezbytné, tzn. nebylo možné zajistit pracovní kapacity jiným způsobem, byla situace ve zdravotnictví a sociálních službách skutečně kritická. V opačném případě by se jednalo o zneužití institutu pracovní povinnost - ani jedna z těchto možností není dobrou vizitkou vlády, potažmo státu.

Pokud již vláda pracovní povinnost nařídila, měla se pokusit překlenout mezery v KrizZ alespoň určitou metodikou, která by sjednotila postup při vydávání pracovních příkazů, stanovila by podmínky, za jakých mohou oprávněná zařízení požádat o ,přidělení“ studentů, za jakých podmínek může být student od pracovní povinnosti osvobozen, jak přistupovat ke studentům, kteři již v nějakém zdravotnickém či sociálním zařízení pracují na základě pracovněprávního vztahu, určit lhůty, kdy má být vyplacena náhrada za uložení pracovní povinnosti atd. Určité zmatky a nejistota ohledně pracovní povinnosti byly omluvitelné v březnu 2020 při počátku tzv. první vlny, vše však nasvědčuje tomu, že nástup tzv. druhé vlny zastihl vládu v mnoha ohledech nepřipravenou.

Nejistá je povaha (právních) vztahů, které vznikaly při výkonu pracovní povinnosti ve zdravotních zařízeních a zařízeních sociálních služeb. S určitou rezervou lze říci, že při výkonu pracovní povinnosti fakticky vznikaly podobné vztahy jako při agenturním zaměstnávání. Vláda společně s hejtmany sehráli roli jakési agentury práce, 
zdravotnická a sociální zařízení pak svým postavením připomínala uživatele práce. Nepochybná je existence určitého právního vztahu mezi orgány krizového řízení (hejtmany, resp. krajskými úřady) a studenty, který vznikl vydáním pracovního příkazu (resp. jeho doručením), vykonáním pracovní povinnosti nap̌r. vzniklo studentům vůči orgánům krizového řízení právo na vyplacení náhrady. Podle příslušných usnesení vlády mohla oprávněná zařízení vznést požadavek na přidělení určitého počtu studentů a na základě takového požadavku měli hejtmani vydávat pracovní příkazy. Oprávněné zařízení pak bylo v pracovním př́íkazu označeno jako místo výkonu pracovní povinnosti. Mezi oprávněným zařízením a studentem vykonávajícím pracovní povinnost vznikal pouze vztah faktický, jehož obsah není upraven žádnými právními předpisy, přesto tato zařízení vůči studentům fakticky vystupovala v roli zaměstnavatele, přidělovala jim práci a rozvrhovala pracovní dobu. Studenti de facto vykonávali závislou práci pro zařízení, ve kterých měli podle pracovních příkazů pracovat. Absence právní regulace vztahu mezi studentem a př́íslušným zařízením může mít přesahy např. do odpovědnostních vztahů, řešeno není ani např. to, kdo má studenty vykonávající pracovní povinnost vybavit ochrannými prostředky.

V souvislosti s výkonem pracovní povinnosti vznikla řada nejrůznějších problémů (nejen právních), níže se pokusím upozornit na alespoň některé z nich.

\section{MÍSTO VÝKONU PRACOVNÍ POVINNOSTI}

Vydávání pracovních příkazů se řídilo místem trvalého pobytu, hejtmani umist'ovali studenty do zařízení v rámci kraje, ve kterém mají nahlášen trvalý pobyt. Studenti však patří mezi skupiny obyvatelstva s největší mobilitou, trvalý pobyt mají zpravidla hlášený u svých rodičů, zejména vysokoškoláci se po značnou část roku zdržují mimo místo svého trvalého pobytu a pobývají v místě, kam docházejí do školy. V místě, kde se nachází jejich škola, mají obvykle pronajatý byt nebo kolej a často tam i pracují. Z důvodu pracovní povinnosti byli studenti nuceni opouštět svá univerzitní města a vracet se do místa svého trvalého pobytu, tj. zpravidla ke svým rodičům či jiným příbuzným, kteří mnohdy patři do ohrožených skupin obyvatelstva. Dále studenti často museli dojíždět do místa výkonu pracovní povinnosti, což znamenalo další náklady, které jim ve většině případů nikdo nenahradí.

\section{NEMOŽNOST PLNIT STUDIJNÍ POVINNOSTI}

Pracovní povinnost znamená pro studenty nemožnost nebo značné ztížení plnění jejich studijních povinností. Přístup a vstřícnost jednotlivých škol vůči studentům vykonávajícím pracovní povinnost se lišila, ovšem ani při větší vstřícnosti škol nelze výkonem pracovní povinnosti nahradit studijní povinnosti, které musí studenti v průběhu studia splnit, pracovní povinnost nelze ve většině případů uznat ani jako praxi, která je nedílnou součástí některých oborů, nebot' neodpovídá jejím požadavkům. Nejžádanějšími studenty byli studenti všeobecného lékařství. Studentům posledních, 6. ročníků na podzim pracovní povinnost nařízena nebyla s tím, že se musí připravovat na státní závěrečné zkoušky. Pracovní povinnost však byla nařízena např. studentům posledního, 5. ročníku farmacie, kteří také skládají státní závěrečné zkoušky, píší diplomovou práci a musí vykonat lékárenskou praxi v celkové délce 6 měsíců při pracovní době 40 hodin 
týdně. Při nařizování pracovní povinnosti zřejmě nikoho nenapadlo, že by studenti farmacie mohli být užitečnější při výkonu praxe v lékárnách než při výkonu nekvalifikovaných prací v nemocnicích, a to v době pandemie, kdy je role lékáren obzvlášt' důležitá. Studenti 4. a 5. ročníků medicíny absolvují blokovou klinickou výuku v rámci jednotlivých oddělení fakultních nemocnic, která je rozvržená do celého akademického roku, přičemž osobní přítomnost na klinické výuce je možné nahradit jen těžko. Důsledkem výkonu pracovní povinnosti může být pro řadu studentů nutnost prodlužování studia a oddalování jejich plného zapojení do praxe, což je zejména v př́padě zdravotnictví trpícího dlouhodobým podstavem kontraproduktivní.

\section{ZTRÁTA PRAVIDELNÉHO P̌̌́IJMU}

Z ekonomického pohledu jsou studenti jednou z nejzranitelnějších skupin obyvatelstva, která nemá dostatečné finanční úspory. Výkon pracovní povinnosti pro některé studenty znamenal nemožnost vykonávat své běžné zaměstnání, které vykonávají souběžně se studiem. Tento výpadek pravidelného příjmu nemohl být v žádném případě kompenzován finanční náhradou za výkon pracovní povinnosti, která není vyplácena průběžně, nýbrž jednorázově, a je splatná do 6 měsíců od skončení nouzového stavu. Výkon pracovní povinnosti mohl řadě studentů způsobit finanční obtíže.

\section{VÝKON NEKVALIFIKOVANÝCH ČINNOSTÍ A NEDŮSTOJNÝ PŘÍITUP}

Zejména studenti nelékařských zdravotnických oborů si v souvislosti s výkonem pracovní povinnosti stěžovali na to, že v nemocnicích museli vykonávat nekvalifikované pomocné práce spočívající např. v úklidu a dezinfekci prostor, ačkoli by jistě byli schopni vykonávat kvalifikovanější činnosti. Využívání studentů vyšších ročníků na takový druh prací nelze považovat za efektivní využívání potenciálu nasazených studentů.

\section{NEDOSTATEK INFORMACÍ}

Studenti podléhající pracovní povinnosti si mohli oprávněně stěžovat na nedostatek informací týkajících se pracovní povinnosti. Z oficiálních míst neměli studenti příliš mnoho možností se dozvědět bližší informace vztahující se k pracovní povinnosti a byli odkázáni na to, co jim přetlumočí jejich školy. ${ }^{27}$ Studenti často nevěděli, zda nejsou povinni se někam automaticky hlásit nebo zda jim za výkon pracovní povinnosti náleží odměna, či nikoli.

\section{PLACENÍ DANÍ A POJISTNÉHO Z POSKYTNUTÉ FINANČNÍ NÁHRADY}

Objektem zájmu širší veřejnosti se pracovní povinnost studentů stala až počátkem ledna 2021, tedy až po jejím zrušení, kdy médii proběhla informace, že finanční náhrada za vykonanou pracovní povinnost by měla podléhat dani z příjmu fyzických osob i odvodům na zdravotní a sociální pojištění nebo že by z tohoto důvodu snad měli studenti

27 Viz např. Důležité informace pro studenty 4. a 5. ročníků a pro dobrovolníky z řad studentů LFP. In: $L e ́-$ kařská fakulta v Plzni, Univerzita Karlova [online]. 23. 10. 2020 [cit. 2021-01-15]. Dostupné na: https:// www.lfp.cuni.cz/clanek/5405-dulezite-informace-pro-studenty-ze-4-a-5-rocniku-a-pro-dobrovolniky -z-rad-studentu-lfp.html. 
část již vyplacených náhrad vracet. ${ }^{28} \mathrm{~V}$ mediálním prostoru jsme se mohli setkat s tvrzením, že stát změnil výklad, ve skutečnosti ale různé orgány státu od počátku zastávaly různý názor.

Finanční správa ve svém sdělení k problematice danění náhrady za pracovní povinnost již v květnu 2020 uvedla: „Peněžní náhradu za nařizený povinný výkon pracovní činnosti podle KrizZ lze posoudit jako peněžitou náhradu za vzniklou újmu (majetkového charakteru). S ohledem na skutečnost, že v běžné situaci by za výkon práce náležela mzda, odměna, resp. náhrada mzdy, která by podle § 6 zákona č. 586/1992 Sb., o daních

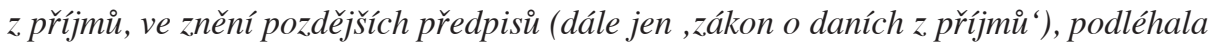
zdanění, nemůže být tato náhrada ,mzdové újmy“ osvobozena od daně z príimů fyzických osob podle $\$ 4$ odst. 1 písm.d) zákona o daních z př́imů a to z di̊vodu, že se jedná o náhradu za ztrátu přijmu dle bodu 1 tohoto ustanovení. Předmětná peněžní náhrada za ,mzdovou újmu“ se posoudí jako př́jem ze závislé činnosti podle § 6 odst. 1 zákona o daních z př́jmů. “29

Tento výklad Finanční správy považuji za nesprávný: na náhradu za výkon pracovní povinnosti nelze automaticky nahlížet jako na náhradu toho, co by osoba s nařízenou pracovní povinností za běžné situace vydělala, a to i z toho důvodu, že se výše náhrady neodvozuje od ztráty výdělku v běžném životě, ale od činnosti, kterou daná osoba v rámci pracovní povinnosti vykonává, právo na výplatu náhrad vzniká i v případě, kdy daná osoba žádnou výdělečnou činnost nevykonává, a nemůže tak o žádný výdělek přijít, což u studentů nebude výjimečné. Jedním z hlavních definičních znaků pracovní povinnosti je její nedobrovolnost. To, co by mělo být kompenzováno, je v prvé řadě právě skutečnost, že osoba byla povolána k výkonu pracovní povinnosti nedobrovolně, pod hrozbou veřejnoprávní trestní sankce, a byla tím značným způsobem vytržena ze svého běžného života.

Naopak Ministerstvo zdravotnictví ve své metodice z dubna 2020 uvedlo následující: , Jelikož se nejedná o mzdu ani plat, nejsou zde zahrnuty povinné odvody na zdravotní a sociální pojištění. "30 Metodika Ministerstva práce a sociálních věcí k pracovní povinnosti z března $2020 \mathrm{k}$ otázce, zda je studentovi za výkon pracovní povinnosti vyplácena mzda/plat poskytovatelem sociálních služeb, uvádí: „, Studentovi náleží peněžní náhrada (nejedná se o mzdu/plat), kterou ${ }^{31}$ je povinen vyplatit orgán krizového řízení do 6 měsíců od ukončení nouzového stavu."

28 Viz např. Medikům zdaní odměny za pomoc. MF DNES. 9. 1. 2021, s. 3.

29 Viz Generální finanční ředitelství. Sdělení v souvislosti s uložením pracovní povinnosti studentům pro poskytování sociálních služeb po dobu nouzového stavu. In: Finanční správa [online]. 27. 5 . 2020 [cit. 202101-15]. Dostupné na: https://www.financnisprava.cz/cs/financni-sprava/media-a-verejnost/nouzovy-stav /danove-informace/info-pro-verejnost/pracovni_povinnost_studentu_po_dobu_nouzoveho_stavu-10699.

30 Viz Ministerstvo zdravotnictví. Doporučený postup pro realizaci uložení pracovní povinnosti studentům pro poskytování zdravotních služeb [online]. 8. 4. 2020 [cit. 2021-01-15]. Dostupné na: https:// koronavirus.mzcr.cz/wp-content/uploads/2020/04/Doporu\%C4\%8Den\%C3\%BD-postup-pro-realizaci -ulo\%C5\%BEen\%C3\%AD-pracovn\%C3\%AD-povinnosti-student\%C5\%AFm-pro-poskytov\%C3 $\% \mathrm{~A} 1 \mathrm{n} \% \mathrm{C} 3 \% \mathrm{AD}-\mathrm{zdravotn} \% \mathrm{C} 3 \%$ ADch-slu\%C5\%BEeb.pdf.

31 Viz Ministerstvo práce a sociálních věcí. Doporučený postup č. 5/2020 pro realizaci uložení pracovní povinnosti studentům pro poskytování sociálních služeb [online]. 24. 3. 2020 [cit. 2021-01-15]. Dostupné na: https://www.mpsv.cz/documents/20142/1443715/Doporu\%C4\%8Den\%C3\%BD+postup +\%C4\%8D.+5_Pracovn\%C3\%AD+povinnost+student\%C5\%AF_VER.II_24_03_2020.pdf/35c2f20a -b8b6-d43c-1712-37e8e0371b21. 
Na webových stránkách České správy sociálního zabezpečení se z článku z 11. ledna 2021 můžeme dozvědět: „, Studenti pomáhající (pracovní povinnost) během pandemie $v$ nemocnicích nebo zařizeních sociálních služeb nemají z vyplacených odměn odvádět povinné pojistné. Tuto povinnost má plátce odměny, tedy kraje. (...) K odměnám studentů, kteři pomáhali během pandemie v nemocnicích a dalšich zařízeních, vydalo Ministerstvo financí již v květnu stanovisko, ve kterém sdělilo, že platí povinnost odvést daň z přijmu. Na základě tohoto stanoviska není možné, aby odměny byly zproštěny povinných odvodi̊. Nutností by bylo přehodnocení výkladu ze strany Ministerstva financí. Příjem studentů při pracovní povinnosti by bylo nutné klasifikovat nikoli jako př́jem ze závislé činnosti, ale jako náhradu újmy (nebo škody) podle občanského zákoníku při aplikaci nařizení pracovní povinnosti. “32 Tento výklad opět není správný, nebot’ náhradu zkrátka nelze považovat za př́ijem ze závislé činnost, jakkoli výkon pracovní činnosti může naplňovat znaky závislé činnosti. Náhradu však nelze považovat za mzdu, plat, odměnu ani jiné obdobné plnění.

Výklad, podle kterého je za osoby vykonávající pracovní povinnost nutné odvádět odvody na nemocenské a důchodové pojištění, by $\mathrm{mj}$. znamenal např̀. to, že v případě vzniku pracovní neschopnosti v průběhu výkonu pracovní povinnosti by studentům vzniklo právo na nemocenské. Jen stěží si ale lze představit, jak by výplata nemocenského či jiných dávek nemocenského pojištění osobám vykonávajícím pracovní povinnost v praxi probíhala. Pracovní nezpůsobilost, a to zřejmě i krátkodobá, je navíc důvodem k osvobození od pracovní povinnosti.

Osoby vykonávající pracovní povinnost nenalezneme výslovně ve výčtu okruhu osob, které by měly být podle zákona č. 187/2006 Sb., o nemocenském pojištění (dále jen „NemPoj“), účastny systému nemocenského pojištění. Účast osob vykonávajících pracovní povinnost je závislá na výkladu § 5 písm. a) NemPoj, podle kterého jsou nemocenského pojištění účastny fyzické osoby, ,,pokud jim v souvislosti se zaměstnáním plynou nebo by mohly plynout př́jmy ze závislé činnosti, které jsou nebo by byly, pokud by podléhaly zdanění v České republice, předmětem daně z přímu podle zvláštního právního předpisu a nejsou od této daně osvobozeny". S ohledem na výše řečené se však domnívám, že toto ustanovení není možné aplikovat, náhradu nelze považovat za př́jem ze závislé činnosti ve smyslu tohoto ustanovení a pracovní povinnost nelze považovat za zaměstnání. Totéž lze konstatovat o pojištění důchodovém.

Bez ohledu na přesný právní výklad lze za absurdní a neudržitelné považovat to, že stát nařídí studentům pracovní povinnost v bezprecedentním rozsahu, znemožní jim tím za cenu zdravotního rizika plnit jejich studijní povinnosti, za což jim podle KrizZ náleží pouze náhrada splatná do 6 měsíců od skončení nouzového stavu, a tato nepř́iliš vysoká náhrada má (resp. může) být ještě snížena o daň z příjmu a platby na pojistné. Příznačné pro současnou krizi je, že se liší výklady jednotlivých ministerstev a dalších úřadů, které nedokázaly své přístupy sjednotit.

Liší se i přístup jednotlivých krajů. Např. Moravskoslezský kraj podle vyjádření své mluvčí nepovažuje pracovní povinnost za výkon závislé práce a peníze za odvedenou

32 Viz Jak je to s povinnými odvody pro studenty, kteří měli pracovní povinnost během pandemie. In: Česká správa sociálního zabezpečení [online]. [cit. 2021-01-15]. Dostupné na: https://www.cssz.cz/web/cz /-/jak-je-to-s-povinnymi-odvody-pro-studenty-kteri-meli-pracovni-povinnost-behem-pandemie. 
práci nepovažuje za mzdu, ale za náhradu. Proto kraj vyplacenou částku nesnižoval o srážku daně z příjmu, ani o odvody na zdravotní a sociální pojištění. ${ }^{33}$ Naopak podle vyjádření mluvčí Středočeského kraje náhrady za pracovní povinnost podléhají všem zákonným odvodům a kraj studentům vyplácí o to sníženou částku. ${ }^{34}$

Nastalou politicky neúnosnou situaci se vláda rozhodla řešit. Dne 11. ledna 2021 vláda svým usnesením uložila ministryni financí, aby připravila „rozhodnutí, kterým za stanovených podmínek dojde k prominutí daně z př́imů poplatníkům, kterým vznikla daňová povinnost $z$ dìvodu př́jmì v podobě peněžní náhrady za vykonání pracovní povinnosti nebo pracovní výpomoci uložené v rámci krizových opatření vlády České republiky po dobu platnosti nouzového stavu vyhlášeného v souvislosti s výskytem epidemie COVID-19, a daně z př́imi̊ poplatníkủm, kterým daňová povinnost vznikla z di̊vodu přijmů v podobě peněžní náhrady poskytnuté po vzájemné dohodě s orgánem krizového ř́zení za dobrovolnou pomoc v rámci krizových opatření vlády České republiky po dobu platnosti nouzového stavu v souvislosti s výskytem pandemie COVID-19“.35 K hromadnému prominutí daně z př́ijmu z důvodu mimořádné události došlo dne 12 . ledna 2021 na základě $\$ 260$ daňového řádu. ${ }^{36}$ Tímto ovšem nebyla vyřešena otázka odvodů, zajímavé bude sledovat, zda př́íslušné orgány státu podniknou konkrétní právní kroky vůči krajům, které za studenty vykonávající pracovní povinnost odvody neplatily. Přes vstřícný krok vlády se domnívám, že jediným z pohledu práva správným, spravedlivým a administrativně nejjednodušším řešením by bylo náhradu nepovažovat za příjem ze závislé činnosti. Nemělo by se též zapomenout na pravidlo in dubio pro libertate, tedy v pochybnostech ve prospěch. Pochybnosti týkající se placení daní a pojistného z náhrady za výkon pracovní povinnosti jsou více než důvodné.

\section{ZÁVĚR}

V první části předkládaného textu jsem se věnoval institutu pracovní povinnosti v obecné rovině, v druhé části jsem se pokusil upozornit na různé aspekty pracovní povinnosti nařízené studentům středních a vysokých škol během současné pandemie. Na pracovní povinnost je možné z určitého úhlu pohledu nahlížet jako na př́pustnou formu nucené práce, která je jinak v demokratickém právním státě obecně nepř́ípustná, společným znakem nucené práce a pracovní povinnosti je nedobrovolnost. Stejně tak ale můžeme pracovní povinnost považovat za něco, co nucenou prací není, ačkoliv nedobrovolnost je společným definičním znakem. V každém př́ípadě pracovní

33 Stát vám děkuje, ale vrat’te třetinu peněz, píší medikům. Mají zpětně danit. iDnes [online]. 8. 1. 2021 [cit. 2021-01-15]. Dostupné na: https://www.idnes.cz/zpravy/domaci/koronavirus-v-cesku-medici-zdaneni -povinne-sluzby-v-nemocnicich-ministerstvo-financi.A210107_151859_domaci_chtl.

34 Tamtéž.

35 Usnesení vlády České republiky ze dne 11 . ledna 2021 č. 31 k vydání rozhodnutí o prominutí daně z příjmů v souvislosti s mimořádnou událostí způsobenou šîrením koronaviru (SARS CoV-2) [online]. [cit. 2021-01-15]. Dostupné na: https://apps.odok.cz/attachment/-/down/IHOABX8NB9QY.

36 Viz Finanční zpravodaj [online]. 2021, č. 5 [cit. 2021-01-15]. Dostupné na: https://www.mfcr.cz/cs /legislativa/financni-zpravodaj/2021/financni-zpravodaj-cislo-5-2021-40540. 
povinnost znamená významný zásah do osobní sféry jednotlivce, pracovní povinnost se dostává do konfliktu s autonomií vůle jednotlivce, bere jednotlivci jeho čas a znemožňuje mu se věnovat činnostem, kterým by se jinak věnoval v běžném životě. Nařízení pracovní povinnosti lze ospravedlnit celospolečenským př́ínosem, který převyšuje dílčí zájmy dotčených jednotlivců - to ji odlišuje od „zakázané“ nucené práce, kterou nijak ospravedlnit nelze. Pracovní povinnost je podle Listiny možné nařídit jen za určitých podmínek - v případě živelních pohrom, nehod nebo jiného nebezpečí, které ohrožuje životy, zdraví nebo značné majetkové hodnoty. I v případě splnění těchto podmínek je nutné zkoumat proporcionalitu nařízení pracovní povinnosti. $V$ žádném př́ípadě by pracovní povinnost neměla být využívána (resp. zneužívána) jako jednoduché řešení systémových problémů.

Zákonná úprava pracovní povinnosti se nachází v KrizZ. Problematika pracovní povinnosti je $\mathrm{v}$ tomto zákoně řešena poměrně stručně a obecně, čímž se otevírá prostor různým nejasnostem. $\mathrm{V}$ důsledku poměrně stručné úpravy mohou vznikat i různé aplikační problémy. Krizové situace však nelze dopředu předvídat a př́liš podrobná a kazuistická zákonná úprava by mohla, stejně jako úprava př́iliš obecná, vést $\mathrm{k}$ aplikačním obtízím. Mezery v zákoně je tak nutné překlenout jasným metodickým řízením ze strany orgánů krizového řízení, zejména vlády.

Výkon pracovní povinnosti neprobíhá v rámci žádného pracovněprávního vztahu, přesto je možné ho považovat za jistou formu závislé práce. To však neznamená, že peněžní náhrada vyplácená za vykonanou pracovní povinnost by měla být považována za př́jem ze závislé činnosti. Náhrada neslouží jako odměna, ale spíše jako určité odškodnění za vzniklou majetkovou i nemajetkovou újmu a nemožnost svobodně se rozhodovat. Problematické je, že náhrada nijak nereflektuje ztrátu výdělku vzniklou v důsledku nemožnosti věnovat se své běžné výdělečné činnosti a je splatná až do 6 měsíců od skončení krizového stavu, $v$ jehož důsledku vznikl nárok na její výplatu.

Pracovní povinnost byla využita při boji s pandemií nemoci covid-19. V rámci obou období nouzového stavu vyhlášených v roce 2020 nařídila vláda hejtmanům ukládání pracovní povinnosti vybraným studentům zdravotnických a sociálních oborů. Účelem nařízené pracovní povinnosti bylo především zajistit dostatek lidských zdrojů při poskytování péče v nemocnicích a zařízeních sociálních služeb. Snad s větším odstupem času bude možné posoudit, nakolik bylo nařízení pracovní povinnosti studentům nezbytné a proporcionální a zda nešlo dostatek personálu v exponovaných zařízeních zajistit jinou, méně invazivní (tedy zejm. pracovněprávní) cestou.

Pracovní povinnost nařízená $\mathrm{v}$ souvislosti s pandemií nemoci covid-19 se neobešla bez problémů. Pro studenty, kterým byl vydán pracovní př́íkaz, znamenala významný zásah do jejich běžného života. Pracovní povinnost byla nařizována podle místa trvalého pobytu, nikoli podle místa, kde studenti studují a tráví většinu času. Studenti byli v mnoha př́ípadech využíváni jako levná pracovní síla a nebylo jim umožněno naplno využít studiem dosažených znalostí a schopností. Pracovní povinnost samožrejmě ztížila nebo i znemožnila studentům vykonávat jejich studijní povinnosti, což může vést $\mathrm{k}$ nutnosti prodlužovat studium. $\mathrm{Z}$ dlouhodobého hlediska může prodlužování studia a nižší produkce absolventů mít negativní důsledky zejména pro zdravotnictví, které se chronicky potýká s nedostatkem personálu. Zkušenosti s pracovní povinností navíc 
neposilují důvěru studentů v český stát a jeho zdravotnictví, což může vést až k jejich budoucímu odchodu do zahraničí.

Problematický je i rozdílný přístup jednotlivých krajů i zařízení, která pracovní povinnost studentů využívala. Stát a zejména vláda neučinil dost pro to, aby byl zajištěn jednotný přístup ke všem studentům, kterým byla pracovní povinnost nařízena. Pomyslným vrcholem byl přístup státu k otázce zdanění a placení odvodů z poskytnutých peněžních náhrad za vykonanou pracovní povinnost. Po řadě protichůdných stanovisek různých orgánů ,zvítězil““ podle mého názoru nesprávný názor Generálního finančního ředitelství a resortu financí, že náhrady jsou př́íjmem ze závislé činnosti a podléhají tak dani z př́ímu fyzických osob, a k tomuto názoru se přiklonila i vláda. Tuto nepříznivou situaci se však vláda rozhodla řešit tak, že uložila ministryni financí, aby studentům daň hromadně prominula, což také učinila.

Řadu problémů, které v roce 2020 nastaly v souvislosti s pracovní povinností studentů, lze jistě svádět na stručnou a podle některých názorů i zastaralou úpravu v krizovém zákoně z roku 2000. Autoři KrizZ zřejmě nepočítali s tím, že by institut pracovní povinnosti mohl být využíván v takovém rozsahu, po takovou dobu a takovým způsobem jako při koronavirové krizi. Je možné diskutovat o tom, jak by měla být úprava v KrizZ zpřesněna, aby se v budoucnu předešlo problémům, které při řešení koronavirové krize vyvstaly. Za vhodnější bych ale považoval, kdyby se v budoucnu orgány krizového řízení držely původního pojetí pracovní povinnost jako zcela výjimečného institutu, který by měl být využíván jen v těch skutečně nejnutnějších případech a po co nejkratší dobu.

Mgr. Pavel Kopecký

Právnická fakulta Univerzity Karlovy

pa.kopecky@seznam.cz 